\title{
Impact of a Major Forest Blowdown Event on Breeding of Ancient Murrelets, Synthliboramphus antiquus, at a Colony in Haida Gwaii, British Columbia
}

\author{
Anthony J. Gaston ${ }^{1,3}$, JAKe Pattison ${ }^{2}$, and Ainsley Brown ${ }^{2}$ \\ ${ }^{1}$ Environment Canada, Science and Technology Branch, National Wildlife Research Centre, Carleton University, Ottawa, \\ Ontario K1A 0H3 Canada \\ ${ }^{2}$ Laskeek Bay Conservation Society, Box 867, Queen Charlotte, British Columbia V0T 1S0 Canada \\ ${ }^{3}$ Corresponding author: tonygastonconsult@gmail.com
}

Gaston, Anthony J., Jake Pattison, and Ainsley Brown. 2015. Impact of a major forest blowdown event on breeding of Ancient Murrelets, Synthliboramphus antiquus, at a colony in Haida Gwaii, British Columbia. Canadian Field-Naturalist 129(3): 285-289.

In the winter of 2010-2011 a large storm blew down an area of about 18 ha of mature coastal rainforest on East Limestone Island, Haida Gwaii, British Columbia. The area supported part of a breeding colony of Ancient Murrelets (Synthliboramphus antiquus). Observations of the timing of chick departures from this section of the colony in 2012 and 2013 suggested that daily timing of chick departures were delayed, on average, by about $30 \mathrm{~min}$, compared with earlier years. This delay may have been caused by debris from the blowdown impeding the progress of chicks over the ground. A sharp decrease in the number of chicks leaving the blowdown area in 2014 may signify that some breeding pairs left the area following reduced breeding success.

Key Words: Ancient Murrelet; Synthliboramphus antiquus; Haida Gwaii; Queen Charlotte Islands; chick departure; blowdown; breeding success

\section{Introduction}

The offshore islands of Haida Gwaii (Queen Charlotte Islands, British Columbia), support an evergreen forest of Western Hemlock (Tsuga heterophylla (Rafinesque) Sargent), Sitka Spruce (Picea sitchensis (Bongard) Carrière), and Western Redcedar (Thuja plicata Donn ex D. Don) (Pojar 2008). Trees in sheltered lowland valleys on the larger islands (e.g., Louise, Lyell, and Burnaby) reach $60 \mathrm{~m}$ in height, while even the smallest, most exposed islands ( $<100 \mathrm{ha})$ support trees up to $40 \mathrm{~m}$ high. On exposed headlands, an open forest of low Sitka Spruce $(<25 \mathrm{~m}$ tall) with grass understory is typical. Many of the smaller, forested islands support breeding colonies of burrow-nesting seabirds, including auks (Cassin's Auklet [Ptychoramphus aleuticus], Ancient Murrelet [Synthliboramphus antiquus], and Rhinoceros Auklet [Cerorhinca monocerata]), and stormpetrels (Fork-tailed Storm-Petrel [Oceanodroma furcata] and Leach's Storm-Petrel [Oceanodroma leucorhoa]) (Rodway 1990).

Although the coastal forests of Haida Gwaii are very resistant to wind damage, periodic storms with hurricane force winds occasionally result in serious blowdown events. These effects are especially likely when the strongest wind gusts emanate from an unusual direction. Patches of regenerating trees give ample evidence of past events, and this regime of frequent disturbance limits the maximum age of stands there, compared with more protected interior forests.

A major blowdown event occurred on islands in northern Laskeek Bay during the winter of 2010-2011, when two large storms passed across the archipelago. The first storm, which occurred in the fall, was accom- panied by hurricane-force winds from the southwest, and the second, in late February, by equally strong winds from the northeast. Winds of such force from both these directions are uncommon on Haida Gwaii; the typical direction of storm-force winds is from the southeast (Thomson 1989). As a result of these storms, trees were broken off or uprooted over about a third of the area of East Limestone Island (Figures 1 and 2), as well as sections of forest on several adjacent islands. The affected area included about half the area of the Ancient Murrelet breeding colony on East Limestone Island.

The breeding biology of Ancient Murrelets at East Limestone Island has been studied since 1990 by the Laskeek Bay Conservation Society. Making use of the long-term data set accumulated by the society before the storm, this paper describes some effects of the blowdown event on the breeding of Ancient Murrelets.

\section{Study Area}

East Limestone Island, off the south-east corner of Louise Island $\left(54^{\circ} 24^{\prime} 25^{\prime \prime} \mathrm{N}, 131^{\circ} 36^{\prime} 44^{\prime \prime} \mathrm{W}\right)$ is 48 ha in extent, with an uneven topography rising to about $50 \mathrm{~m}$ above sea level. Most of the island supports typical Sitka Spruce-Western Hemlock-Western Redcedar forest, but a swath of the south coast is covered in Red Alder (Alnus rubra Bongard). In the interior of the island, a small number of large trees have apparently remained standing through several cycles of blowdown. The island has never been exposed to industrial logging activities, although a small number of trees may have been taken opportunistically from shorelines in the past. Understory vegetation is sparse or absent over most of the island because of intensive deer browsing (Stockton et al. 2005). Ancient Murrelets nest in burrows over 


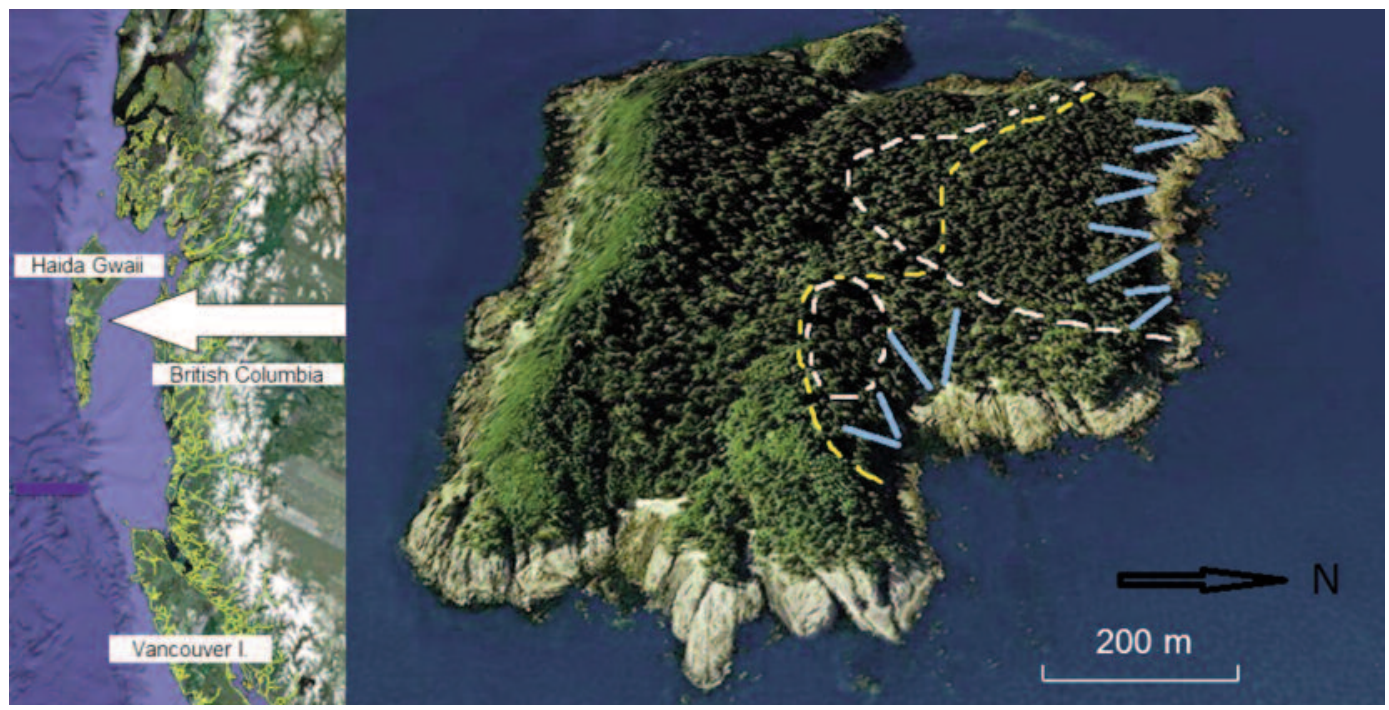

FIgURE 1. Aerial view of East Limestone Island, Haida Gwaii, British Columbia, seen from the east. The area of the blowdown is enclosed by white dashes, the Ancient Murrelet (Synthliboramphus antiquus) breeding area is north and east of the yellow dashes, and the original chick funnels are shown in blue. Left inset map shows the position of East Limestone Island on the coast of British Columbia. Images from Google Earth, data SIO, NOAA, US Navy, NGA, GEBCO C2015 Cnes/Spot image. Image (C2015 DigitalGlobe.
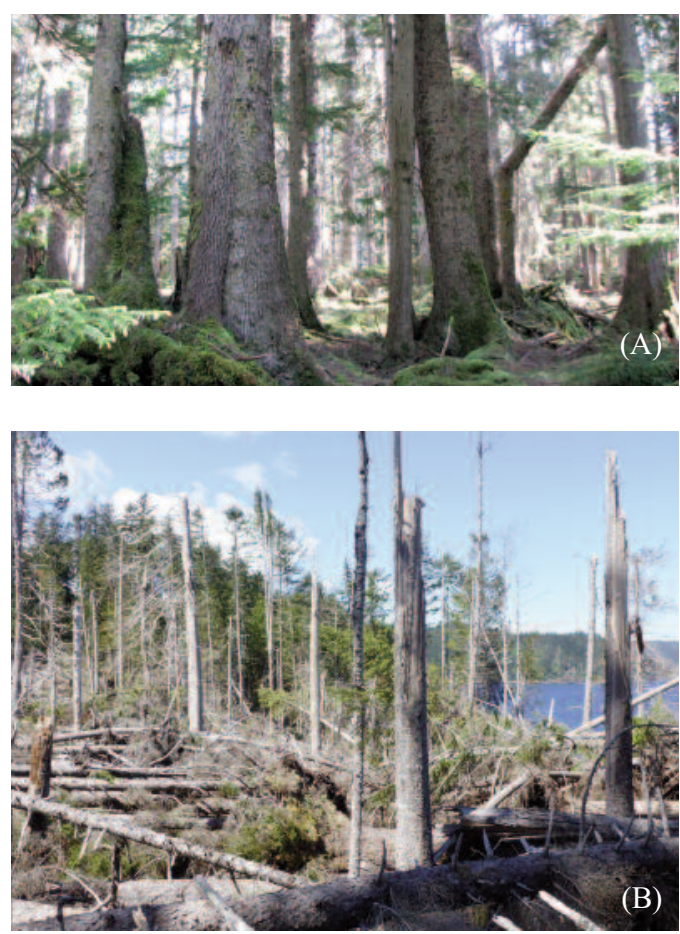

FIGURE 2. A section of the forest on East Limestone Island, Haida Gwaii, British Columbia, (A) before the storm in winter 2010-2011 and (B) after the storm. Photos: Laskeek Bay Conservation Society. about half the island, mainly in an arc along the east and north coasts extending inland up to $300 \mathrm{~m}$ (Figure 1). In 2006, the Ancient Murrelet population was estimated at 506 breeding pairs (Lemon 2007).

\section{Methods}

One- to two-day old Ancient Murrelet chicks leave the burrow at night and make their way through the forest to the shore. Chicks depart after dark, usually between 2300 and 0130 , and do so only after the arrival of the off-duty parent, so that the entire family leaves the burrow together (Jones et al. 1987). The parents then fly directly to the sea where they rendezvous with the chicks (Gaston 1992). The transit from burrow to shore normally takes 30-60 minutes. Typically, more than $90 \%$ of chicks reach the sea by 0230 (Gaston 1992).

Since 1990, a portion of departing chicks at East Limestone Island has been trapped en route to the sea using plastic fences ("funnels"), which intercept them and guide them to a trapping station close to the shore (Figure 1), where the time of arrival is recorded and chicks are weighed and banded (Gaston and Descamps 2011). Trapping was carried out between 2230 and 0230 nightly from 7 May until, after the end of May, no chicks were trapped on two nights in succession. Traps were inspected every 15 minutes; thus, times of arrival of chicks at the bottom of the funnels may have been up to 15 minutes earlier than their time of capture. The position of the funnels was kept constant from year to year. Four funnels were positioned to intercept chicks departing from the north shore of the island (funnels 1-4) and 
records of departing chicks at these sites were obtained from 1990-2006 and in 2010.

After the blowdown in the winter of 2010-2011, fallen trees and branches prevented the deployment of most of the plastic fences for funnels 1-4. However, clearance of debris allowed funnels to be constructed on the site of funnels 3 and 4 in 2012-2014. Funnel mouths were situated in their former position, but the guide fences were shorter and in some cases rerouted, so that the area from which trapped chicks originated was smaller. Instead of inspecting the funnels throughout the night, infrared motion activated cameras (PC900 HyperFire Professional Covert IR, Reconyx Inc., Holmen, Wisconsin, USA) were set up at the mouth of each funnel to photograph chicks passing through a wooden trough, about $12 \mathrm{~cm}$ wide at the seaward end of each funnel (Figures 3 and 4). When triggered, the cameras were set to take 10 photographs at 1 -sec. intervals. Each image was time- and date-stamped, so that the time of arrival of each chick could be determined from subsequent inspection. In 2012, the cameras were operated for only a few nights as a pilot scheme. In 2013 and 2014, they were operated nightly from 2200 until after dawn, when the media storage cards were collected and downloaded.

The time at which chicks were photographed was compared with the time of capture of chicks in funnels 1-4 in earlier years, using the period 1996-2003, during which the population was relatively stable after a period of population decline caused by Raccoon (Procyon lotor) predation (Gaston and Descamps 2011) and before another period of decline after 2003. All times are given in Pacific Daylight Time (GMT $+9 \mathrm{~h}$ ). Changes in numbers of chicks recorded between 2013 and 2014 at the reconstructed funnels 3 and 4 were compared with numbers recorded at funnels 5 and 6 , where the catchment area was less affected by fallen trees (Figure 1).

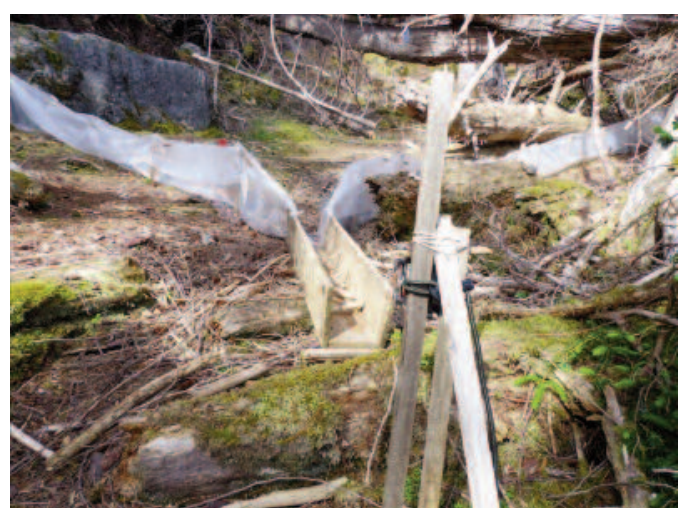

FIGURE 3. Set up for recording, showing a motion-detector camera, plastic funnel fences, and an exit trough. Photos: Laskeek Bay Conservation Society.

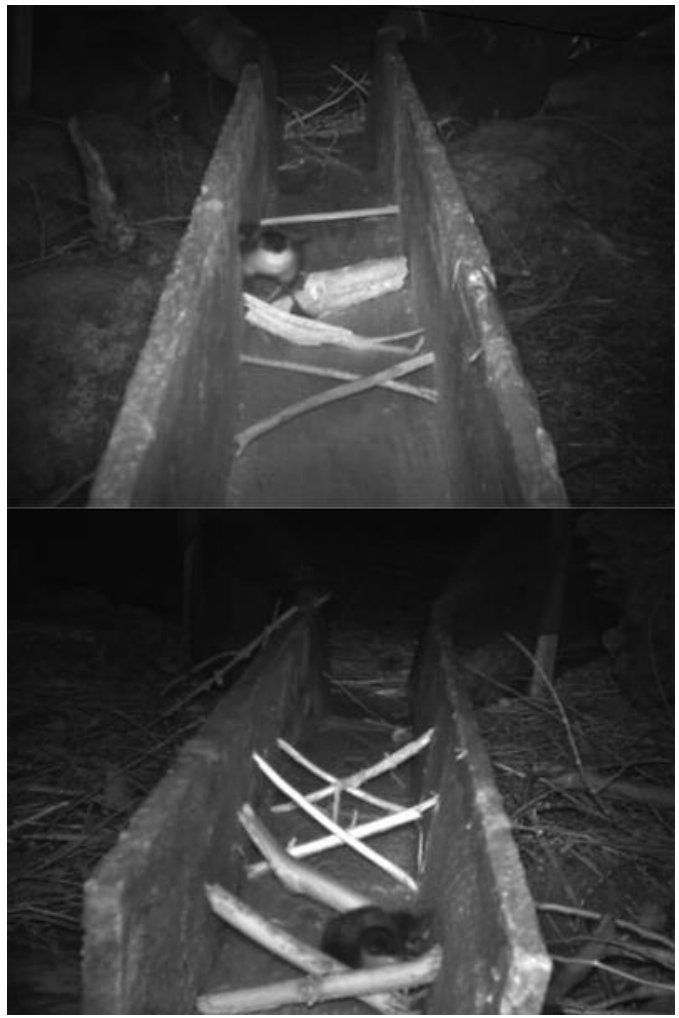

FIGURE 4. Two Ancient Murrelet (Synthliboramphus antiquus) chicks making their way through an exit trough. Twigs were placed across the troughs to slow the chicks and ensure that they were captured on camera. Photographs of adult murrelets, deer mice, and deer were also recorded by the cameras. Photos: Laskeek Bay Conservation Society.

\section{Results}

The number of chicks trapped at funnels 1-4 during 1996-2003 averaged $327 \pm 70$ (SD) a year. In 2013, 67 chicks were recorded on camera and judged from the time intervals to be different individuals, but this included 14 chicks passing the cameras after 0230, the cut-off point for observations in earlier years. In 2014, only 13 were recorded on camera (a decrease of $81 \%$ from 2013). In contrast, 85 chicks were recorded at funnels 5 and 6 in 2013 and 75 in 2014 (a 12\% decrease).

In 2013, chicks were recorded on camera from 0012 to 0519 (mean 0136); $43 \%$ of the chicks photographed by 0230 arrived before 0100 and $23 \%$ after 0200 (mean 0115). In 2012, only seven images of departing chicks were obtained, with a mean arrival time of 0115 for those photographed before 0230 , identical to the timing in 2013. In 2014, 13 chicks were photographed, with a mean arrival time of 0050 and $50 \%$ recorded before 0100. Chicks passing through funnels $1-4$ in 1996-2003 were captured as early as 2247 , with $61 \%$ captured before 0100 and only $7 \%$ after 0200 (mean 0050). There was little inter-year variation (Figure 5). A com- 
parison of the distribution of captures during 19962003 with photographic records during 2013 showed that those in 1996-2003 were significantly earlier (Wilcoxson test, $Z=2.52, P=0.01$; Figure 6).

\section{Discussion}

Arrival of chicks at the bottom of funnels 3 and 4 in 2012 and 2013 was later than in 1996-2003 despite the fact that trapping times in earlier years could have been up to 15 minutes later than arrival times because of the trap inspection interval. Taken together, the results suggest that, after the blowdown, the passage of chicks through the forest to the shore was extended by about 30 minutes compared with earlier conditions.
Several explanations are possible for the chicks' delay in reaching the bottom of the funnels: adults could have been delayed in returning to their burrows if they were disorientated because of changes in the structure of the forest or higher light intensity resulting from elimination of canopy foliage. Alternatively, chicks were impeded during their transit through the forest by debris from the fallen trees. Chicks do not depart from their burrows until the off-duty parent arrives (Gaston 1992), so any delay by the parent will also delay the chicks. However, by chick departure date, the parents would have visited their burrows for inspection and incubation changeovers many times that season and should have known the new landscape intimately. Al-

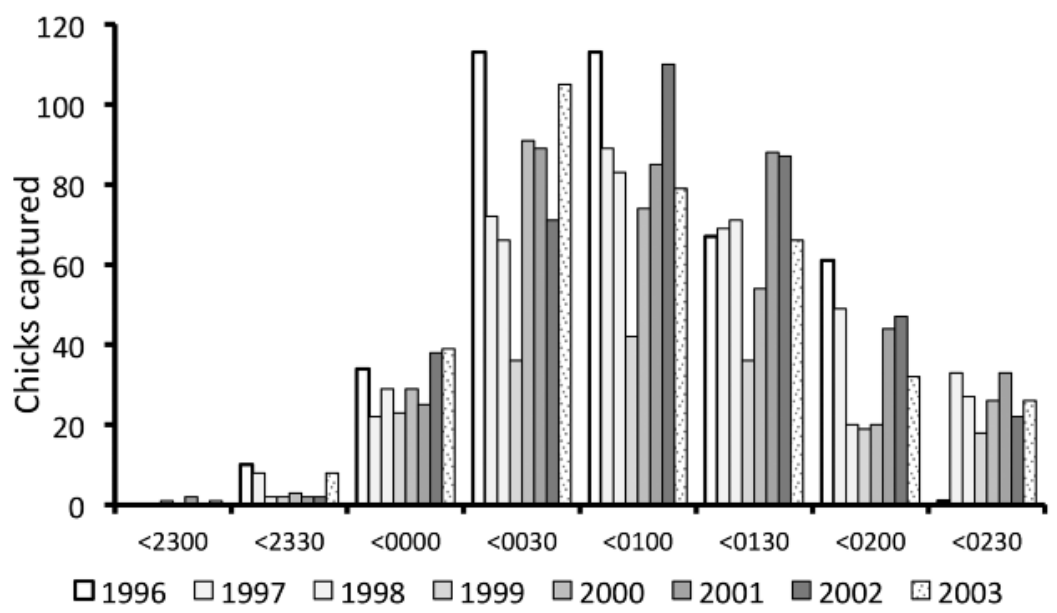

FIGURE 5. Numbers of Ancient Murrelet (Synthliboramphus antiquus) chicks captured in funnels 1-4 on East Limestone Island, Haida Gwaii, British Columbia, during 1996-2003 by 30-minute periods.

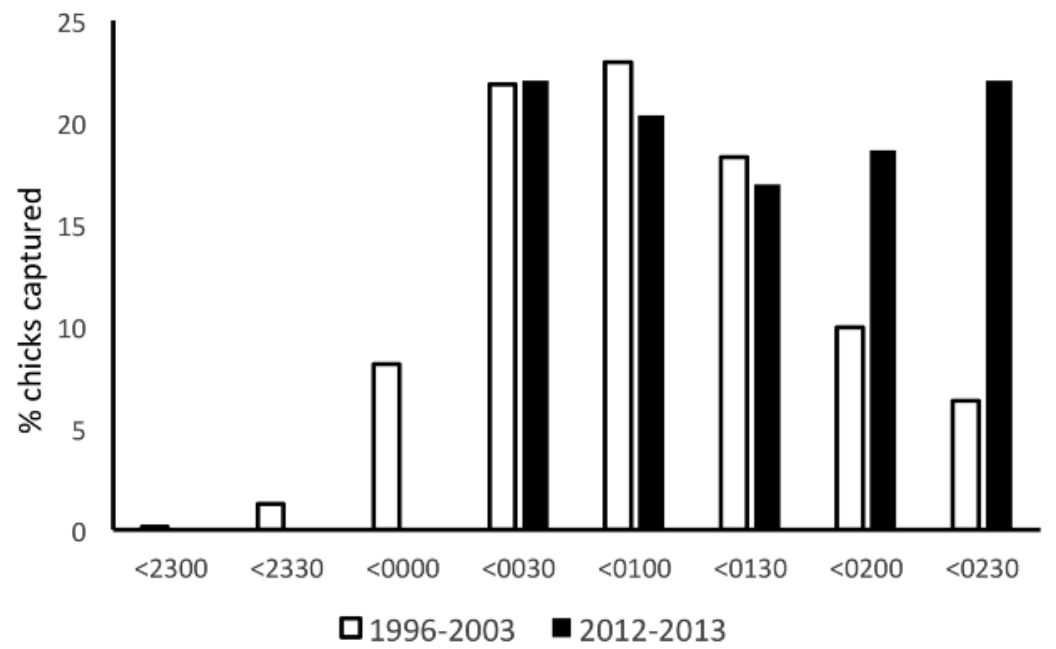

FIGURE 6. Percentage of Ancient Murrelet (Synthliboramphus antiquus) chicks captured in 1996-2003 compared with those captured in 2012 and 2013, by 30-minute periods. 
though light levels certainly affect the time of arrival of adults, parents that are due to depart that night with chicks are usually among the first to arrive at the colony (Jones et al. 1987; Gaston 1992), and, in any case, the darkest time of night occurs at about 0100 . With many chicks arriving at the bottom of the funnels after 0200 in 2013, light seems unlikely to have been the main cause of the delay.

Hence, the most likely cause of the delay in the departure of chicks was probably their slower progress on the ground, presumably because of debris from the blowdown. In any case, delays from any cause might have reduced the chance of a successful rendezvous with the parents, especially in the case of chicks arriving after first light (0430). Moreover, some chicks may not have reached the shore on the night of their departure, making eventual reunion with their parents impossible. Delays in the departure process, regardless of whether they caused reproductive failure, may have induced parents to relocate their breeding site away from the area of funnels $1-4$, resulting in the steep reduction in the number of departures witnessed in 2014 - a decrease not seen at funnels 5 and 6 , which were in areas less affected by the blowdown.

Chicks that were photographed in 2014 arrived at the shore at about the same time as those observed in pre-blowdown years, suggesting that parents of chicks starting close to the shore or otherwise unimpeded in their departure were those that continued to use the area of funnels $1-4$, whereas those whose chicks were significantly delayed either refrained from breeding or shifted elsewhere.

As the blowdown area regenerates, vegetation close to the ground will probably become denser, and we expect that numbers of chicks originating from the area of funnels $1-4$ will decline further in future, a process unlikely to reverse for several decades. Although East Limestone Island supports only a small colony of Ancient Murrelets, the nearby Reef Island supports several thousand breeding pairs (Gaston 1992), and half of that colony area was affected by similar blowdowns, suggesting that the event may have significant repercussions for the regional population of Ancient Murrelets.

\section{Acknowledgements}

We thank all the volunteers and staff who contributed to Ancient Murrelet studies on East Limestone Island since 1990. For comments on the manuscript we thank Keith Moore.

\section{Literature Cited}

Gaston, A. J. 1992. The Ancient Murrelet: A Natural History in the Queen Charlotte Islands. T. \& A. D. Poyser, London, UK.

Gaston, A. J., and S. Descamps. 2011. Population change in a marine bird colony is driven by changes in recruitment. Avian Conservation and Ecology 6: 5 .

Jones, I. L., J. B. Falls, and A. J. Gaston. 1987. Colony departure of family groups of ancient murrelets. Condor 89: 940-943.

Lemon, M. J. F. 2007. East Limestone Island Ancient Murrelet colony survey, June 2006. Laskeek Bay Research 15: 67-86.

Pojar, J. 2008. Changes in vegetation in Haida Gwaii in historical time. Pages 32-36 in Lessons From the Islands: Introduced Species and What They Tell Us about How Ecosystems Work (Special Publication). Edited by A. J. Gaston, T. E. Golumbia, J.-L. Martin, and S. T. Sharpe. Canadian Wildlife Service, Environment Canada, Ottawa, Ontario, Canada.

Rodway, M. S. 1991. Status and conservation of breeding seabirds in British Columbia. Pages 43-102 in Seabird Status and Conservation: a Supplement (Technical Publication 11). Edited by J. P. Croxall. International Council for Bird Preservation, Cambridge, UK.

Stockton, S. A., S. Allombert, A. J. Gaston, and J.-L. Martin. 2005. A natural experiment on the effects of high deer densities on the native flora of coastal temperate rain forests. Biological Conservation 126: 118-128.

Thomson, R. E. 1989. The Queen Charlotte Islands Physical Oceanography. Pages 27-63 in The Outer Shores. Edited by G. G. E. Scudder and N. Gessler. Queen Charlotte Island Museum Press, Skidegate, British Columbia, Canada.

Received 17 February 2015

Accepted 12 July 2015 